\title{
Early Holocene Human Remains from the Argentinean Pampas: Cranial Variation in South America and the American Peopling
}

\author{
Lumila P. Menéndez and S. Ivan Perez \\ CONICET-División Antropología, Facultad de Ciencias Naturales y Museo Universidad Nacional de La Plata, \\ Argentina
}

\section{Héctor M. Pucciarelli and Mariano Bonomo}

CONICET-División Antropología, Museo de La Plata, Universidad Nacional de La Plata, Argentina

\section{Pablo G. Messineo and Mariela E. Gonzalez}

CONICET-INCUAPA, Facultad de Ciencias Sociales, Universidad Nacional del Centro de la Provincia de Buenos Aires, Olavarría, Argentina

\section{Gustavo G. Politis}

CONICET-INCUAPA, Facultad de Ciencias Sociales, Universidad Nacional del Centro de la Provincia de Buenos Aires, Olavarría, Argentina; and División Arqueología, Museo de La Plata, Universidad Nacional de La Plata, Argentina

Morphological comparisons between the earliest and latest human skeletons of America have suggested the existence of a complex scenario underlying the biological diversification of American populations. In the late nineteenth and early twentieth centuries Florentino Ameghino initiated the debate on the antiquity of humans in the Argentinean Pampas, which has been reviewed recently due to new radiocarbon dates obtained. Morphometric analyses from these Argentinean Pampas samples are presented together with early samples from Chile, Brazil, and Colombia. Results show that while there is no clear separation between early and late samples from Chile, samples from Brazil, Colombia, and Argentina show more pronounced differences, the latter presenting the largest morphological variation among early American samples. However, the hypotheses that morphological differences between early and late American samples are related to evolutionary processes are difficult to support using cranial morphometric differences alone. Future studies need to consider a combination of additional evidence (e.g., archaeological and molecular).

Keywords American peopling, craniofacial variation, Argentinean Pampas, Lynch's diversification test

\section{Introduction}

The biological variation of Pleistocene-Holocene American populations has been the focus of intense research for more than 150 years (e.g., Chatters et al. 2014; González-José et al. 2008; Hrdlička 1912; Hubbe et al. 2010; Lahr 1996; Lund 1842; Neves and Pucciarelli 1991; Perego et al. 2009; Stringer

Correspondence to: Lumila P. Menéndez. Email: lumilam@fcnym.unlp.edu.ar; lumilam@gmail.com
1992; Turner 1983). Most of these investigations comprise a wide variety of studies concerning the peopling of the Americas, which have been the subject of continued debates (Goebel et al. 2008; Powell and Neves 1999). The large interest raised by this issue is partially due to the fact that South America was the last continent to be colonized by modern humans (after the Late Glacial Maximum) in association with an apparently fast spread across the region and with relatively high levels of morphological, cultural, and linguistic 
diversity found among Native American populations (Goebel et al. 2008; Perez et al. 2009; Powell and Neves 1999; Pucciarelli et al. 2006; Sardi et al. 2005).

Comparative morphological analyses between the earliest and latest American human skeletons have been the main source of discussion for studying diachronic changes on the biological variation of American populations. These studies have suggested the existence of a complex scenario underlying the biological diversification of American populations (de Azevedo et al. 2011; González-José et al. 2008; Menéndez et al. in review; Neves and Hubbe 2005; Perez et al. 2009; Powell and Neves 1999; Pucciarelli et al. 2010). The wide morphological variation recognized has been grouped into two sets that correspond to the early and late chronologies: a set of skulls characterized by a long and narrow cranial vault and narrow face is associated with early Holocene ages; and another set of skulls that exhibit short and wide cranial vault together with a wide face, being related to late Holocene ages. From the beginning of the research, different models have been proposed to explain this large morphological variation: (1) a three-wave model, based on linguistic, dental, and genetic evidence, states that the ancestors of modern Native Americans would have come from eastern Asia in three separate migratory waves at different times (Cavalli-Sforza et al. 1994; Greenberg et al. 1986); (2) a two-wave model based on morphological evidence argues the existence of a major discontinuity in morphological variation between late Pleistocene/ early Holocene and late Holocene human remains, attributed to two diachronic migratory events from Asian populations (Neves et al. 2003, 2007; Powell and Neves 1999; Pucciarelli et al. 2010); and (3) a series of studies based on molecular evidence (Chatters et al. 2014; Kemp et al. 2007; Rasmussen et al. 2014) propose a one-wave model in which the coalescence of most modern Native Americans is traced back to a unique ancestral population of eastern Asia and posterior diversification is a product of different micro-evolutionary processes. Given these findings of molecular studies, recent morphological studies (de Azevedo et al. 2011; González-José et al. 2008) propose an alternative model of recurrent gene flow in which genetic and morphological diversity of American populations is explained as the result of significant recurrent gene flow between American and Asian populations after the first migratory wave.

These recent studies, however, have not included early Holocene human remains from the Argentinean Pampas to build and evaluate these models (see exceptions in Perez et al. 2009; Pucciarelli et al. 2010). These human remains are important because, despite the large morphological variation of the area (Pucciarelli et al. 2010; Sardi et al. 2005), the Southern Cone of South America was one of the latest regions to be inhabited by human populations. The comparison of craniometric morphology of these skulls with several late and early Holocene skulls from different regions of South America have the potential to yield results about the relative importance of different evolutionary processes for explaining the morphological diversity of American populations.

In this paper, we present a craniometric analysis of eight early Holocene human skeletons from the Argentinean Pampas (Figure 1). This sample is compared to several samples of the final late Holocene to estimate the rate of evolutionary change in this region. We also compare the craniometric morphology of these skulls with several late and early Holocene skulls from different regions of South America (Lagoa Santa in Brazil; Camarones 14 in Chile; and Aguazuque, Checua, and Tequendama in Colombia). Evolutionary rates of morphological diversification are calculated for each region to evaluate the relative importance of evolutionary processes for explaining morphological diversification. Taking into consideration the pattern of cranial variation observed in previous studies, the goals of this work are: (1) to investigate whether a pattern exists of two different cranial morphologies that correspond to early and late chronologies as observed in previous studies for other regions (Neves and Hubbe 2005; Neves and Pucciarelli 1991; Pucciarelli et al. 2003); (2) to consider whether this pattern occurs in all the regions studied in South America as a result of the same evolutionary processes (Brace et al. 2001; González-José et al. 2001, 2003; Jantz and Owsley 2001; Mena et al. 2003; Neves et al. 1999; Steele and Powell 1992, 1993); and (3) to evaluate whether the rate of evolutionary change is similar among South American regions (González-José et al. 2005). Finally, we discuss alternative explanations to understanding early cranial variation and differences between early and late American samples.

\section{Argentinean Pampas samples and the American peopling}

The absence of Argentinean Pampas samples from the discussion of American peopling and diversification can be related to several reasons. In the late nineteenth and early twentieth centuries, Ameghino (1889, 1910a, $1910 \mathrm{~b}$ ) opened the discussion about the great antiquity of humans in the vast grasslands of the Argentinean Pampas. Several findings of human skulls and bones with supposedly archaic physical features were used 


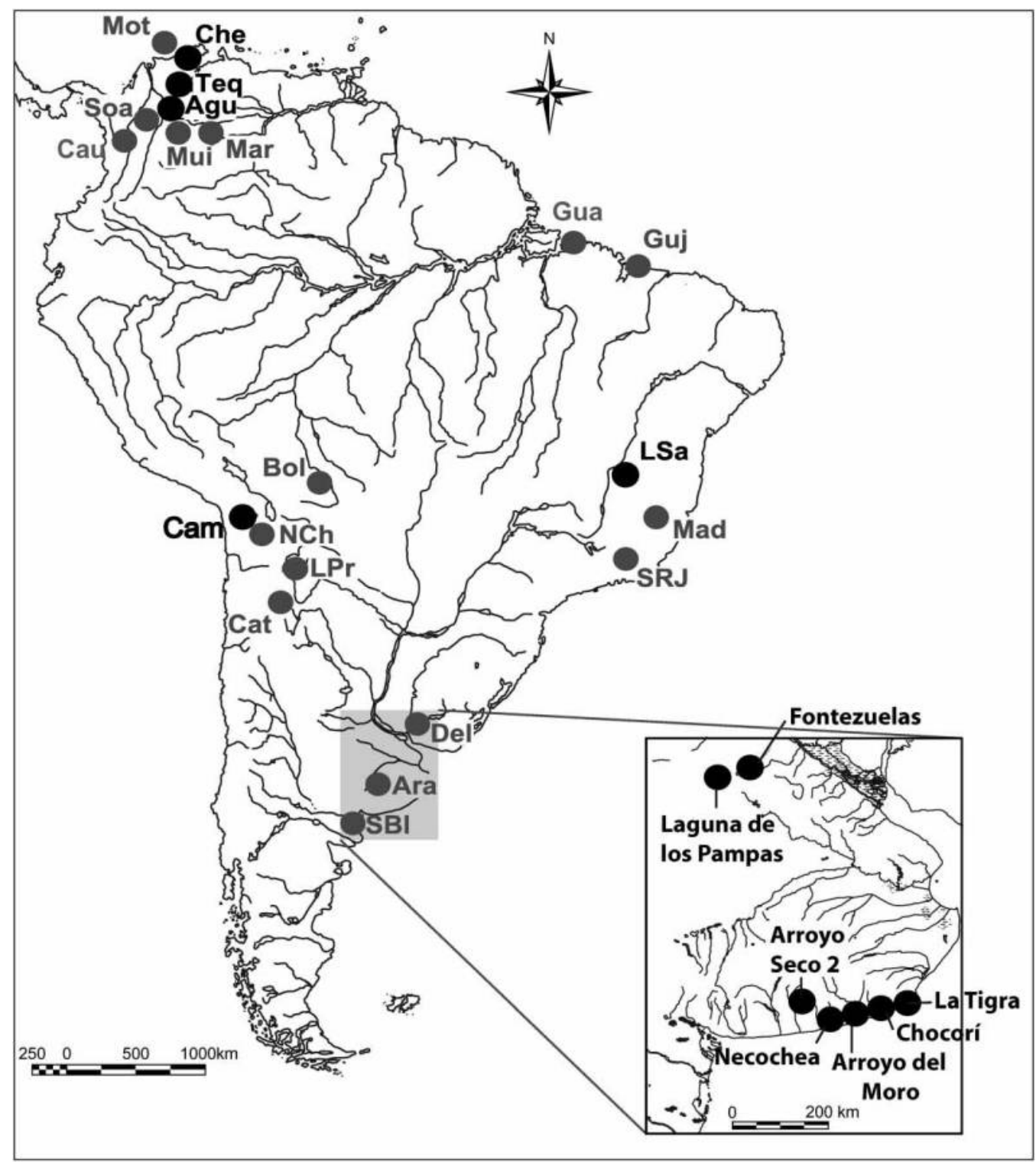

Figure 1 Map showing the geographic locations of the South American cranial samples analyzed (sample abbreviations: Agu: Aguazuque; Ara: Araucano; Bol: Bolivia; Cam: Camarones 14; Cat: Catamarca; Cau: Cauca; Che: Chequa; Del: Delta; Guj: Guajajara; Gua: Guarani; LPr: Las Pirguas; LSa: Lagoa Santa; Mad: Madalena; Mar: Marin; Mot: Motilon; Mui: Muisca; NCh: NorChile; SRJ: Sambaqui Norte/Rio; SBI: San Blas; Soa: Soacha; Teq: Tequendama). Early samples are shown as black circles, late samples as grey circles. Early Pampean samples are shown in detail with the full archaeological site name.

by Ameghino to support the taxonomic identification of different extinct hominid species. These fossils were attributed to a Tertiary age, and Ameghino proposed that the Pampas were inhabited by humans in that period (Ameghino 1880, 1906). Furthermore, they were interpreted as proof of an early process of hominid evolution in the Southern Cone of South America, unconnected from those of other parts of the world (Ameghino 1884, 1907, 1909, 1910a, 1912). Although some of his ideas ignited a heated debate at that time regarding the origin and antiquity of humans in the Argentinean Pampas and their subsequent biological differentiation and dispersion (see Bonomo 2002; Daino 1979), these issues have since become obsolete. However, Ameghino must be acknowledged as the originator of a scientific discussion that lasted for decades and boosted related archaeological and bio-anthropological studies, as well as debates throughout southern South America (Politis et al. 2011; Pucciarelli et al. 2010). Nevertheless, the inclusion of samples of early human remains from the Argentinean Pampas has been only recently recognized due to the AMS radiocarbon dating of some samples obtained by Ameghino and coworkers (Bonomo et al. 2013; Politis and Bonomo 2011; Politis et al. 2011). Even though Ameghino was wrong in assessing an Argentinean origin for the genus Homo and all Old World human fossil specimens (Podgorny 2015), at least some of the remains he studied, for example the Arroyo de Frías skeleton, actually are among the oldest samples of southern South America (Cornero et al. 2014; Jackson et al. 2012). 
Table 1

Archaeological samples included in this study

\begin{tabular}{|c|c|c|c|c|c|}
\hline Country & Period & Sample & Code & $n$ & Main museum* \\
\hline \multirow[t]{7}{*}{ Argentina } & Early Holocene & Pampa & Pam & 8 & INCUAPA-MLP-MACN \\
\hline & Late Holocene & Araucano & Ara & 11 & MLP \\
\hline & & Catamarca & Cat & 13 & MLP \\
\hline & & Delta & Del & 11 & MLP \\
\hline & & Las Pirguas & $\mathrm{LPr}$ & 11 & MLP \\
\hline & & San Blas & $\mathrm{SBI}$ & 17 & MLP \\
\hline & & Fontezuelas & Fon & 1 & MUC \\
\hline \multirow[t]{8}{*}{ Brazil } & Early Holocene & Lagoa Santa-Sumiduoro & LSaS & 25 & ZMUC \\
\hline & & Lagoa Santa-Cerca Grande & LSaC & 6 & MNUFRJ \\
\hline & & Lagoa Santa-Lapa & LSaL & 8 & MNUFRJ \\
\hline & Late Holocene & Guajajara & Guj & 12 & MNUFRJ \\
\hline & & Guarani & Gua & 9 & MNUFRJ \\
\hline & & Madalena & Mad & 8 & MNUFRJ \\
\hline & & Sambaqui Norte & SRJ & 12 & MNUFRJ \\
\hline & & Sambaqui Rio & SRJ & 27 & MNUFRJ \\
\hline \multirow[t]{3}{*}{ North Chile/South Bolivia } & Early Holocene & Camarones 14 & Cam & 5 & MNHN \\
\hline & Late Holocene & Bolivia & Bol & 18 & MLP \\
\hline & & NorChile & NCh & 14 & $\mathrm{MDH}$ \\
\hline \multirow[t]{9}{*}{ Colombia/Venezuela } & Early Holocene & Aguazuque & Agu & 27 & $\mathrm{ICN}$ \\
\hline & & Chequa & Che & 9 & ICN \\
\hline & & Tequendama & Teq & 10 & MNC \\
\hline & Late Holocene & Cauca & Cau & 11 & $\mathrm{MDH}$ \\
\hline & & Marin & Mar & 20 & MNC \\
\hline & & Motilon & Mot & 8 & ICAS-FLS \\
\hline & & Muisca & Mui & 38 & $\mathrm{MDH}$ \\
\hline & & Soacha & Soa & 13 & MNC \\
\hline & & Total & & 352 & \\
\hline
\end{tabular}

*ICAS-FLS: Instituto Caribe de Antropología y Sociología de Fundación La Salle (Venezuela); ICN: Instituto de Ciencias Naturales (UNC, Colombia); INCUAPA: UE INCUAPA-CONICET (Investigaciones Arqueológicas y Paleontológicas del Cuaternario Pampeano, Facultad de Ciencias Sociales, UNICEN); MACN: Museo Argentino de Ciencias Naturales "Bernardino Rivadavia" (Buenos Aires, Argentina); MDH: Musée de l'Homme (Paris, France); MLP: Museo de La Plata (La Plata, Argentina); MNC: Museo Nacional de Colombia (Bogotá, Colombia); MNHN: Museo Nacional de Historia Natural (Santiago, Chile); MNUFRJ: Museu Nacional Universidade Federal de Rio de Janeiro (Rio de Janeiro, Brazil); ZMUC: Zoological Museum University of Copenhagen (Copenhagen, Denmark).

Among the early Pampean findings, eight early Holocene Argentinean Pampas samples from six archaeological sites (Arroyo La Tigra, Necochea, Arroyo Chocorí, Arroyo del Moro, Arroyo Seco 2, and Laguna de Las Pampas) are presented and discussed in this paper (Figure 1, Table 1). The radiocarbon dates were processed at different laboratories, and some of them received special treatments because of their relevance and potential antiquity. For example, three of them (La Tigra, Chocorí, and Fontezuelas) were pretreated by T. Stafford who discriminated the most abundant and stable amino acids. All calibration ages were obtained with the software Calib 6.0 (Stuiver and Reimer 2011), using two sigma ranges.

The Fontezuelas skeleton (ZMK 11/1885) was discovered and excavated by Santiago Roth, two or three $\mathrm{km}$ from the Arrecifes creek. These human remains were found in association with extinct megamammal bones, among them a Glyptodon carapace that was supposedly covering the skeleton. The human bones were bought and sent to the Zoologisk Museum of Copenhagen University, at the end of the nineteenth century. Although Roth (1888), Virchow (1883), Ameghino (1889), and Lehmann-Nitsche (1907) believed in the synchronicity of both remains, and therefore they proposed a Pleistocene age for the human skeleton, a phalanx was dated and yielded an age of 1823-1927 cal yr BP (Politis and Bonomo 2011). A scute carapace was also processed but it did not yield age information due to lack of collagen. It seems clear that the human skeleton and the Glyptodon carapace were not synchronous and therefore they were in a false association. The Fontezuelas skull was considered in the present work, along with the late Holocene samples.

The skeleton from Arroyo La Tigra (also named Miramar; MLP 401) was found by Andrés Canesa, a bone collector who worked at Museo de La Plata, a few $\mathrm{km}$ south of Mar del Sur, a seaside town by the Atlantic coast. The skeleton was deposited in the Museo de La Plata. Ameghino made assumptions about its supposed primitive features, and thus the skeleton was assigned to the earliest forms of hominid corresponding to the species Homo pampaus (Ameghino 1909), a native South American species that would have inhabited the Pampas region during the Tertiary and migrated to other continents using land bridges that connected them. Recently, a radius fragment from La Tigra was dated to 7939-8171 cal yr BP (Politis et al. 2011).

The skeleton from Necochea (MACN-Pv 5008) was found in a littoral dune near the seaside city of 
Necochea by the Ameghino brothers, Carlos and Florentino, who traveled and visited the area in 1909. Florentino Ameghino recognized in this skeleton the same ancestral physical features he had observed in the skeleton from Arroyo La Tigra, and therefore he assigned it to Homo pampaus. A total of five skeletons were collected in these findings, and they were deposited in the Museo Nacional de Buenos Aires (currently Museo Argentino de Ciencias Naturales "Bernardino Rivadavia"). The right talus of specimen MACN-Pv 5008 was dated to 7670-7936 cal yr BP (Bonomo et al. 2013; Politis and Bonomo 2011).

The two human skeletons from Arroyo del Moro were found in blowout depressions of coastal or littoral dunes lying between the La Malacara and El Moro creeks (Lobería district). These remains were presented by Ameghino at the 17th American International Scientific Conference, held in July 1910 in Buenos Aires. Both skeletons were dug out and sold to the Museo Nacional de Buenos Aires by Lorenzo Parodi. The morphological and metric features of these skeletons, also known as "the Malacara skeletons", allowed Ameghino to define, in 1910, the extinct species Homo sinemento, which was considered to be another human ancestor (Ameghino 1910b). According to Ameghino's evolutionary scheme, this new ancestor supported the idea that local hominid diversification occurred in the Argentinean Pampas during the Tertiary period. Both skeletons are studied in the present paper. A vault fragment (MACN-Pv 5141) was dated and yielded an age of 7566-7838 cal yr BP (Bonomo et al. 2013; Politis and Bonomo 2011).

The last two early Pampean sites studied in this paper (Arroyo Seco 2 and Laguna de Las Pampas) correspond to modern excavations, which were performed under the direction of G. Politis and involved several researchers from different disciplinary fields (Politis et al. 2012, 2014). The archaeological site Arroyo Seco 2 is located a few $\mathrm{km}$ from the city of Tres Arroyos. At this site, which has been excavated for the last three decades, 44 human skeletons were recovered in primary and secondary burials. The individuals studied here, AS-19 and AS-8, were dated to 8349-8559 cal yr BP (Politis et al. 2014). The other site, Laguna de Las Pampas, is located along the margin of the homonymous lake in the southeast Lincoln district (northwest Buenos Aires province), and it was excavated during 2009. A total of ten individuals ( 8 adults and 2 sub-adults), together with faunal remains and lithic tools, were collected along the lake margins. A radiocarbon date of 9760-10,227 cal yr BP was obtained from the human remains of a single individual that was found buried and partially articulated (Burial 1). A second radiocarbon date was obtained from a tooth belonging to a sub-adult individual found in a surface position close to Burial 1 (20 m south), which yielded an age of 9554-9963 cal yr BP (Politis et al. 2012). Only the skull from Burial 1 is included in the present article.

\section{Materials and methods}

A total of 352 non-artificially modified skulls of adult individuals from 35 American archaeological sites were analyzed for the present study. Samples were classified into 25 groups according to their early or late chronology and spatial location of provenance: five from North Chile, eight from Colombia, eight from Brazil, and four from the Argentinean Pampas. Samples were grouped into geographical regions for studying the evolutionary history of human populations that inhabited each area. Even though geographic proximity does not equal the same kinds of relatedness among early and late samples in all regions, we assume that there was no gene flow-or at least that it was low-among the geographical regions in which we organized the samples studied. Chronologically, 254 skulls correspond to the late Holocene and 98 to the early Holocene (Table 1). Late Holocene samples include only male individuals so as to not introduce morphological variation due to sexual dimorphism, while early Holocene samples include most males and some few female individuals. Previous studies where analyses of male and female individuals were done separately, show similar comparative results (Neves and Hubbe 2005), so individuals of both sexes were included among the early samples to increase the number of early individuals in the analysis. Eight individuals (six male and two female) of this latter period are from the Argentinean Pampas (Table 2), 27 come from Aguazuque (Colombia), 10 from Tequendama (Colombia), 9 from Checua (Colombia), 39 from Lagoa Santa (Brazil), and 5 from Camarones 14 (North Chile).

To study the morphological variation in early and late South American populations, 30 craniofacial variables were defined on the basis of functional cranial theory (Table 3). This theoretical framework was inspired by van der Klaauw's (1948-1952) mid-twentieth century theory of the independent function of cranial components in mammals, as well as by later studies by Moss and Young (1960). Functional craniology argues that a skull is composed of a relatively independent set of hierarchically organized cranial units, named modules with particular growth and differentiation processes, whose size and shape depend on the demands of the soft tissues and cavities which serve as support and protection (Pucciarelli 2008). The above-mentioned method has already been applied in human and nonhuman primate studies 
Table 2

Radiocarbon dates from human bone of the Argentinean Early Holocene archaeological samples included in the present study

\begin{tabular}{|c|c|c|c|c|c|c|}
\hline Archaeological site & District & $n^{*}$ & Excavated by & $\begin{array}{l}\text { Radiocarbon date } \\
\left({ }^{14} \mathrm{C} \text { yr BP }\right)\end{array}$ & $\begin{array}{l}\text { Calibrated date }{ }^{\star *} \\
\text { (cal yr BP, } 2 \sigma \text { range) }\end{array}$ & Museum ID ${ }^{\star \star \star}$ \\
\hline Arroyo Chocorí & Mar del Sur & 1 & F. Larrumbe & $7010 \pm 60$ & 7673-7880 & MLP-400 \\
\hline Arroyo La Tigra & Mar del Sur & 1 & A. Canesa & $7270 \pm 60$ & 7939-8171 & MLP-401 \\
\hline Necochea & Necochea & 5 & C. and F. Ameghino & $7013 \pm 67$ & 7670-7936 & MACN-5008 \\
\hline Arroyo del Moro & Lobería & 2 & L. Parodi & $6885 \pm 73$ & $7566-7838$ & MACN-5141 \\
\hline Arroyo Seco 2 & Tres Arroyos & 45 & G. Politis and coworkers & $7700 \pm 60$ & 8349-8559 & AS- 19 and AS-8 \\
\hline \multirow[t]{2}{*}{ Laguna de los Pampas } & Lincoln & 10 & G. Politis and coworkers & $8971 \pm 77$ & $9760-10,227$ & L.LLP.S2.2 \\
\hline & & & & $8835 \pm 83$ & 9554-9963 & L.LLP.S2.43 \\
\hline
\end{tabular}

${ }^{*}$ Corresponds to the total number of specimens recovered in the archaeological site.

${ }^{* *}$ CALIB 6.0.1 Program (using SHCal04).

${ }^{* * *} \mathrm{ID}$ of the specimens studied in the present work.

with successful results (e.g., Pucciarelli et al. 1990, 2006, 2010). In the present article, all measurements were collected by one researcher (HMP). Some of the samples used in this study were poorly preserved, which is expected for older archaeological samples. For small samples, the existence of missing data is one of the most important problems. Since multivariate morphometric analyses require that the data sets are complete, missing observations were estimated by multiple estimations (Rubin 1987). This method, which has been widely used by other researchers (e.g., Béguelin 2011; Bernal 2008), replaces the lost data by simulated values, which are generated from the covariation structure of known variables (Rubin 1987).

The original craniofacial measurements were used to calculate ratios or Mosimann shape variables, obtained by dividing each original variable by the geometric mean (GM) of all variables, computed as the $n$th root of the product of the $n$ variables (Jungers et al. 1995). Then, a principal component analysis (PCA) was performed, based on a covariance matrix of the ratios. The first PC scores are a low-dimensional representation of the Euclidean distance matrix among samples, and as such they provide interesting graphical displays to study between-group morphological differences. These principal components (PCs) constituted the shape variables used in posterior analysis. A PCA was performed over the total individual values comparing late and early Holocene samples. Also, PCAs for each region (Argentinean Pampas, Brazil, Colombia, and North Chile) were done comparing early and late Holocene archaeological sites.

The expected magnitudes and evolutionary patterns of shape and size under the influence of genetic drift and mutations alone were evaluated using Lynch's (1990) neutral expectation for the $\Delta$ evolutionary rate. Lynch estimates that the lower and upper limits for evolutionary rates of mammalian skeletal traits under the neutral mutation-drift hypothesis are $\Delta \min =0.0001$ and $\Delta \max =0.01$, respectively. Thus, the null hypothesis of neutrality is accepted for $\Delta$ values between 0.0001 and 0.01 . According to this author, a low rate suggests that non-random factors have played a predominant role in preventing phenotypic evolution, while a high rate implies an acceleration of morphological evolution by directional nonrandom factors (e.g., migration, gene flow, directional selection, phenotypic plasticity (Perez and Monteiro 2009)). A range of evolutionary times was used to assess how long the separation among populations would have to be for the observed $\Delta \mathrm{s}$ to fall within the expected interval (Table 4). The $\Delta$ rate test allows for the comparison of evolutionary rates for each region (Argentinean Pampas, Brazil, Colombia, and North Chile) of South America. Lynch's $\Delta$ evolutionary rate was calculated separately for craniofacial size (given by the previously calculated GM) and shape (PC1 and PC2) variables. Size and shape variables were analyzed separately, as previously reported differences between early and late samples include variation in both variables (Pucciarelli et al. 2010). Only PC1 and PC2 were included because they were considered representative of morphological variation, as together they explained a large percentage of morphological variation. It is expected that the first PC score shows changes associated with size differences.

\section{Results}

The PCA of the ratio variables (i.e., Mossiman shape variables) of all individuals with early and late chronologies shows that the early Holocene samples are separated from the late Holocene ones along the second PC axis (Figure 2(A)). While PC1 seems to show the allometric component of variation - that is variation in shape influenced by variation in size-PC2 shows variation in shape. Size seems to contribute substantially to the differentiation of early Holocene from late Holocene samples. Differences between early and late Holocene samples are related mostly to general-rather than local-changes. The main changes were found in neurocranial length, height and breadth, facial breadth, and masticatory height (Table 5). Early Holocene skulls at the positive 
Table 3

Cranial measurements employed in this study

\begin{tabular}{|c|c|c|c|}
\hline Number & Symbol & Name & Description* \\
\hline 01 & $\mathrm{NL}$ & $\begin{array}{l}\text { Neurocranial } \\
\text { length }\end{array}$ & Nasion-Opisthocranion ${ }^{\star * *}$ \\
\hline 02 & NW & $\begin{array}{l}\text { Neurocranial } \\
\text { width }\end{array}$ & Euryon-Euryon*** \\
\hline 03 & $\mathrm{NH}$ & $\begin{array}{l}\text { Neurocranial } \\
\text { height }\end{array}$ & Basion-Vertex*** \\
\hline 04 & $\mathrm{FL}$ & Facial length & Inner Prosthion-Vomerbasio ${ }^{\dagger}$ \\
\hline 05 & FW & Facial width & 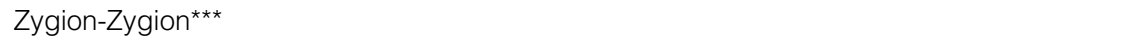 \\
\hline 06 & $\mathrm{FH}$ & Facial height & Nasion-Prosthion*** \\
\hline 07 & ANL & $\begin{array}{l}\text { Anteroneural } \\
\text { length }\end{array}$ & Glabella-Bregma*** \\
\hline 08 & ANW & $\begin{array}{l}\text { Anteroneural } \\
\text { width }\end{array}$ & Pterion-Pterion ${ }^{\star * \star}$ \\
\hline 09 & ANH & $\begin{array}{l}\text { Anteroneural } \\
\text { height }\end{array}$ & Bregma-Vomerbasio $^{\dagger}$ \\
\hline 10 & MNL & Midneural length & Bregma-Lambda*** \\
\hline 11 & MNW & Midneural width & similar as NW \\
\hline 12 & $\mathrm{MNH}$ & Midneural height & Basion-Bregma*** \\
\hline 13 & PNL & $\begin{array}{l}\text { Posteroneural } \\
\text { length }\end{array}$ & Opisthion-Opisthocranion ${ }^{\star \star *}$ \\
\hline 14 & PNW & $\begin{array}{l}\text { Posteroneural } \\
\text { width }\end{array}$ & Asterion-Asterion*** \\
\hline 15 & $\mathrm{PNH}$ & $\begin{array}{l}\text { Posteroneural } \\
\text { height }\end{array}$ & Lambda-Opisthion*** \\
\hline 16 & OTL & Otic length & $\begin{array}{l}\text { Distance from the external auditory meatus to the midpoint of the inner border of the } \\
\text { petrous bone } e^{\ddagger}\end{array}$ \\
\hline 17 & OTW & Otic width & External auditory meatus width ${ }^{\ddagger}$ \\
\hline 18 & $\mathrm{OTH}$ & Otic height & External auditory meatus height ${ }^{\ddagger}$ \\
\hline 19 & OL & Optic length & Dacryon-superior orbital fissure \\
\hline 20 & OW & Optic width & Dacryon-Ectoconchion*** \\
\hline 21 & $\mathrm{OH}$ & Optic height & 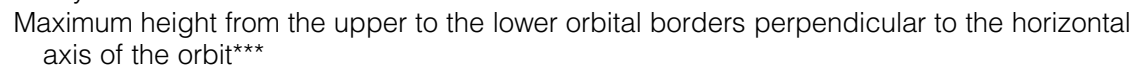 \\
\hline 22 & $\mathrm{RL}$ & Respiratory length & 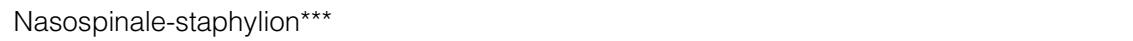 \\
\hline 23 & RW & Respiratory width & Left alare-right alare ${ }^{\star \star \star}$ \\
\hline 24 & $\mathrm{RH}$ & Respiratory height & Nasion-Nasospinale ${ }^{\star \star *}$ \\
\hline 25 & $\mathrm{ML}$ & Masticatory length & Distance from the zygomaxillare anterior ${ }^{* * *}$ to the posterior margin of the glenoid fossa ${ }^{\ddagger}$ \\
\hline 26 & MW & Masticatory width & $\begin{array}{l}\text { Distance from the anterior border of the sphenoid bone in the greater wing to the lower } \\
\text { point of the zygotemporal suture }\end{array}$ \\
\hline 27 & $\mathrm{MH}$ & Masticatory height & Distance from the stephanion ${ }^{\diamond}$ to the lower point of the zygotemporal suture ${ }^{\ddagger}$ \\
\hline 28 & $\mathrm{AL}$ & Alveolar length & Prosthion-alveolon*** \\
\hline 29 & AW & Alveolar width & Left ectomolare-right ectomolare ${ }^{\star \star \star}$ \\
\hline 30 & $\mathrm{AH}$ & Alveolar height & $\begin{array}{l}\text { Palatal deep on the palatine suture, measured by place the lateral arms of the palatometer } \\
\text { on the left and right ectomolare }{ }^{\ddagger}\end{array}$ \\
\hline
\end{tabular}

*See Buikstra and Ubelaker (1994), Howells (1973), Knussman (1988), Martin and Saller (1959), Pucciarelli (2008), Pucciarelli et al. (2010), and Steele and Bramblett (1988) for landmark definitions and measurement descriptions.

${ }^{\star *}$ For the projected measurements, the skull must be placed laterally on a square $50 \times 50-\mathrm{cm}$ white cardboard, for reaching an acceptable parallelism with the caliper bar and/or its branches. Positioning must be done by carefully rotating the skull up to reach an auricular-infraorbitary equalization (Frankfurt line). Previously, the correct anterior-posterior and vertical placement of the skull must be ensured by the equalization of the prosthion and inion points with respect to the horizontal plane, and by the positioning of the palatal first molars perpendicularly to this plane. The Frankfurt orientation can be facilitated by a nylon thread placed not more than $1 \mathrm{~cm}$ above the skull and held parallel to one of the cardboard lines. The thread must be taken away after the correct placement has been reached and before measurement starts. Direct measurements may be made from the Frankfurt orientation. It is recommended to take all projected measurements first and then all direct measurements or vice versa.

${ }^{* \star * B}$ Buikstra and Ubelaker (1994), Howells (1973), and Steele and Bramblett (1988).

${ }^{\dagger}$ The point of intersection of the vomer and the basioccipital in the median sagittal plane.

${ }^{\ddagger}$ Pucciarelli (2008) and Pucciarelli et al. (2010).

${ }^{\circ}$ The point where the upper temporal line cuts the coronal suture (Steele and Bramblett 1988).

extreme of $\mathrm{PC} 2$ are longer and narrower, whereas in the negative extreme late Holocene skulls are wider and shorter.

Furthermore, in the PCA scatterplot of all the early samples together (see Figure 2(B)), the Colombian (Tequendama and Checua) skulls are separated along the first PC axis from the Brazilian (Lagoa
Santa), North Chile (Camarones 14) and Pampas samples. In the positive extreme of $\mathrm{PC} 1$ and the negative extreme of PC2, Lagoa Santa samples are separated from Colombian samples (Aguazuque, Checua, Tequendama), which are located in the negative extreme of $\mathrm{PC} 1$ and positive extreme of $\mathrm{PC} 2$. Camarones 14 samples had an intermediate position 
Table 4

Chronology and ranges of evolutionary time

\begin{tabular}{|c|c|c|c|c|c|c|}
\hline Sample & $\begin{array}{l}\text { Mean early } \\
\text { chronology }\end{array}$ & $\begin{array}{l}\text { Calibrated } \\
\text { chronology }\end{array}$ & $\begin{array}{l}\text { Mean calibrated } \\
\text { chronology }\end{array}$ & $\begin{array}{c}\text { Late } \\
\text { chronology }\end{array}$ & $\begin{array}{l}\text { Generation } \\
\text { time }\end{array}$ & $t$ \\
\hline Pampa & 7654 & $8222-8543$ & 8382 & 500 & 28 & 281.50 \\
\hline Colombia & 6081 & 6680-7149 & 6914 & 500 & 28 & 229.07 \\
\hline $\begin{array}{l}\text { North } \\
\text { Chile }\end{array}$ & 7000 & $7670-7930$ & 7800 & 500 & 28 & 260.71 \\
\hline Brazil & 8166.67 & 8779-9268 & 9023 & 500 & 28 & 304.39 \\
\hline
\end{tabular}

located between Brazilian and Colombian samples, nearer to the latter ones.

It should be noted, however, that the Pampas samples present great variation scattered throughout the distribution. One of the samples from Arroyo Seco 2 was grouped with the Colombian samples, such as

A

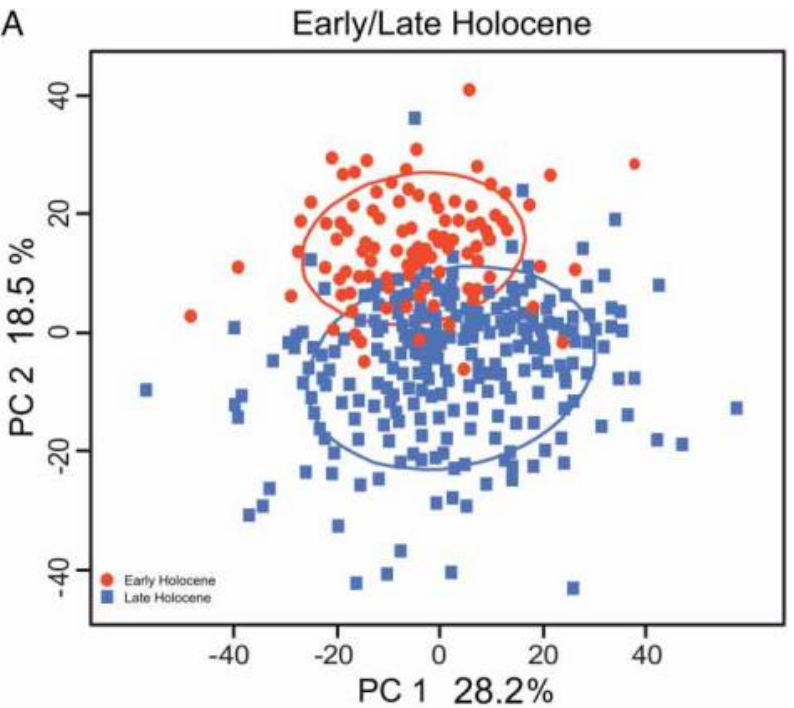

B

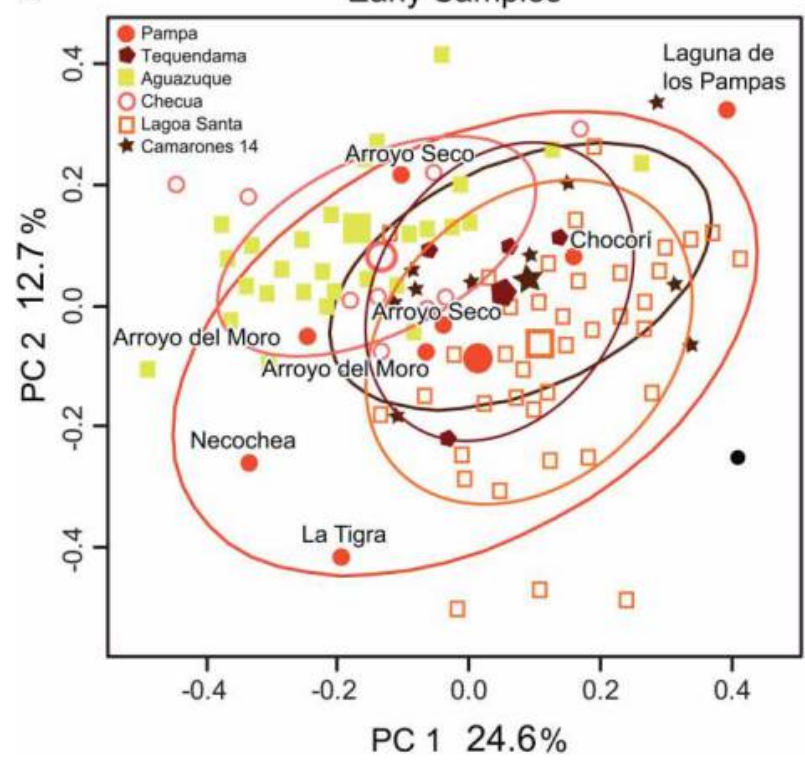

Figure 2 PCAs, with (A) all individuals grouped by early and late, and (B) all early individuals grouped by region and association with early Pampas samples. Large symbols indicate the sample means.
Aguazuque and Checua, while both Arroyo del Moro skulls were grouped with Camarones 14. Chocorí clustered with the Lagoa Santa and Tequendama samples. The other ones (Laguna de Las Pampas, La Tigra, and Necochea) remain on the margins of the distribution, near the specimens from Lagoa Santa. The main variation among the early samples is due to neurocranial length, facial breadth, and the masticatory area (Table 5).

Although in general terms, these patterns remained when we performed PCAs for each region, the results obtained presented some variation, and some local differences became important. In all region, the main variables that contribute to generate differences between early and late samples were associated with neurocranial length and/or facial breadth, which were also the craniometric variables that differentiate early samples inwardly (Table 5). Figure 3(a) and 3(d) display morphological variation in the Pampas and Colombian PCAs along the first PC score, which seems to be related to the temporal dimension. Along the first PC score of both distributions, early human-remains samples are located on the right side while late samples are grouped to the left. Differences between early and late Holocene samples from the Argentinean Pampas are related mostly to changes in bizygomatic breadth, neurocranial length and breadth, basion-bregma height, occipital length, biasterionic breadth, and sphenoid-zygotemporal breadth (Table 5). Late samples seem to be wider than the early ones; thus, they have a wider face and neurocranium, but a narrower masticatory breadth. Similarly, in the Colombian sample, most changes are related to cranial length, breadth, and height, as well as facial breadth and basion-bregma height (Table 5). In agreement with the overall results, early samples are longer and higher while late ones are shorter and lower. Figure 3(b) shows the Brazil PCA, in which cranial morphological variation due to chronology can be observed along the second PC score. The Brazil early and late samples present somewhat more superimposition along the first PC axis than the Pampas and Colombian samples. Component loadings (Table 5) show that numerous variables contribute to explain this chronological 
Table 5

Component loadings of the PCA (abbreviations of the first column correspond to the cranial measurements of Table 3; bold numbers indicate the higher and lower values)

\begin{tabular}{|c|c|c|c|c|c|c|c|c|c|c|c|c|}
\hline & \multicolumn{2}{|c|}{ Early/Late } & \multicolumn{2}{|c|}{ All Early } & \multicolumn{2}{|c|}{ Pampa } & \multicolumn{2}{|c|}{ N Chile } & \multicolumn{2}{|c|}{ Brazil } & \multicolumn{2}{|c|}{ Colombia } \\
\hline & CP1 & CP2 & $\mathrm{CP} 1$ & CP2 & CP1 & CP2 & CP1 & CP2 & CP1 & CP2 & CP1 & CP2 \\
\hline NL & 4.849 & 5.506 & 6.521 & 0.612 & 4.052 & -8.018 & 7.558 & 3.479 & 3.689 & 0.012 & 7.536 & 3.253 \\
\hline NW & 3.851 & -5.877 & 2.728 & -1.634 & 6.120 & 2.703 & 2.009 & -1.420 & 4.313 & 3.031 & -7.683 & 4.531 \\
\hline $\mathrm{NH}$ & 5.312 & 3.109 & 3.589 & 1.021 & 5.603 & 0.570 & 5.159 & -1.350 & 3.474 & -4.710 & 5.241 & 5.221 \\
\hline $\mathrm{FL}$ & 2.479 & 1.020 & 2.586 & 1.473 & 3.517 & 0.366 & 3.022 & 0.607 & 1.074 & -0.050 & 2.095 & 1.749 \\
\hline FW & 6.054 & -4.035 & 4.444 & -1.562 & 8.358 & 1.693 & 3.424 & 1.518 & 6.483 & 4.014 & -3.899 & 6.012 \\
\hline $\mathrm{FH}$ & 3.531 & -0.827 & 3.717 & 3.023 & 3.458 & -0.255 & 3.285 & 0.573 & 3.666 & 2.695 & 0.971 & 2.334 \\
\hline ANL & 1.170 & 1.019 & 1.792 & -1.281 & 1.455 & -3.307 & 3.022 & 4.311 & 0.480 & 3.328 & 1.592 & 0.535 \\
\hline ANW & 3.234 & -4.023 & 2.039 & -5.871 & 4.765 & 1.897 & -0.119 & -1.230 & 3.707 & 1.034 & -5.475 & 3.576 \\
\hline ANH & 4.940 & 1.654 & 3.064 & 0.153 & 5.287 & -0.388 & 4.767 & -1.400 & 4.523 & -2.130 & 3.174 & 3.936 \\
\hline MNL & 3.284 & 4.312 & 3.633 & 2.687 & 2.052 & -3.861 & 4.419 & 0.907 & 3.347 & -2.820 & 5.572 & 2.511 \\
\hline MNW & 3.853 & -5.881 & 2.715 & -1.617 & 6.123 & 2.704 & 2.041 & -1.420 & 4.304 & 3.084 & -7.683 & 4.531 \\
\hline $\mathrm{MNH}$ & 5.809 & 2.584 & 3.384 & 0.139 & 6.146 & 1.425 & 4.588 & -2.030 & 4.737 & -3.240 & 4.886 & 5.501 \\
\hline PNL & -0.361 & 3.269 & 1.244 & 1.989 & -0.390 & -5.736 & 4.040 & 4.535 & -1.360 & 3.039 & 4.150 & -1.273 \\
\hline PNW & 2.513 & -1.714 & 2.215 & -3.280 & 4.674 & -0.544 & 1.432 & -0.100 & 1.513 & 0.878 & -2.512 & 3.040 \\
\hline $\mathrm{PNH}$ & 4.590 & 0.521 & 3.737 & -3.863 & 5.747 & -2.462 & 4.829 & -6.070 & 5.108 & -3.090 & 0.905 & 2.851 \\
\hline OTL & 2.278 & -0.887 & 2.097 & 0.477 & 3.299 & 0.545 & 1.462 & -0.130 & 2.068 & 0.455 & -0.482 & 1.414 \\
\hline OTW & 0.603 & 0.073 & 0.391 & 0.053 & 0.659 & -0.441 & 0.488 & 0.032 & 0.481 & -0.170 & 0.312 & 0.171 \\
\hline OTH & 0.986 & 0.213 & 0.508 & -0.149 & 1.657 & -0.456 & 0.675 & 0.072 & 0.967 & -0.360 & 0.424 & 0.213 \\
\hline OL & 0.984 & 0.832 & 0.473 & 0.479 & 0.788 & 0.327 & 0.867 & 0.246 & 0.652 & -0.870 & 1.391 & 0.472 \\
\hline OW & 0.977 & -0.217 & 0.477 & -0.665 & 1.060 & 0.044 & 0.817 & 0.732 & 0.595 & 0.083 & -0.240 & 0.865 \\
\hline $\mathrm{OH}$ & 0.650 & -0.355 & 0.279 & 0.035 & 0.283 & 0.004 & 0.732 & 0.613 & 0.839 & 0.772 & -0.345 & 0.460 \\
\hline $\mathrm{RL}$ & 1.900 & 0.168 & 1.671 & 0.331 & 3.187 & -0.612 & 2.043 & 0.619 & 1.588 & 0.265 & 0.696 & 1.185 \\
\hline RW & 0.430 & -0.151 & 0.465 & 0.066 & 0.316 & 0.141 & 0.394 & 0.064 & 0.172 & 0.300 & -0.046 & 0.637 \\
\hline $\mathrm{RH}$ & 2.172 & -0.425 & 2.194 & 1.472 & 2.588 & -0.548 & 1.847 & 0.471 & 2.043 & 1.361 & 0.355 & 1.595 \\
\hline ML & 2.332 & 1.768 & 1.837 & 0.707 & 1.099 & -0.782 & 2.181 & -1.050 & 1.131 & -1.900 & 2.625 & 1.438 \\
\hline MW & 0.924 & -0.327 & 0.639 & 1.452 & -0.25 & 0.996 & 0.540 & 0.257 & 1.510 & -0.100 & -0.259 & 0.906 \\
\hline $\mathrm{MH}$ & 4.260 & 1.328 & 4.474 & 2.342 & 3.939 & -1.208 & 5.158 & -2.840 & 3.840 & 0.137 & 2.941 & 3.371 \\
\hline $\mathrm{AL}$ & 1.890 & 0.455 & 1.534 & 0.813 & 2.286 & 0.067 & 2.710 & 0.126 & 0.985 & -0.220 & 0.955 & 1.553 \\
\hline AW & 2.454 & -1.429 & 1.153 & -2.148 & 2.930 & 0.225 & 2.113 & 0.271 & 2.094 & -0.270 & -2.261 & 2.110 \\
\hline $\mathrm{AH}$ & 0.924 & -0.330 & 0.647 & -0.411 & 1.138 & 0.359 & 0.870 & -0.060 & 0.768 & 0.444 & -0.352 & 0.913 \\
\hline
\end{tabular}

variation: bizygomatic breadth, cranial breadth and height, parietal chord, basion-bregma height, occipital length, biasterionic breadth, and auditory meatus length. Skulls from the late Holocene are higher than early ones, which seem to be wider and longer. Finally, North Chile samples, as seen in Figure 3(c), are superimposed and present little temporal differences; however, like in other geographical regions, the main changes are in neurocranial length and height and masticatory height (Table 5).

The results of Lynch's $\Delta$ evolutionary rate for size (GM) and shape (PC1 and PC2) are presented in Table 6. The values for the Colombian and Chilean GM fall into the range of the neutral hypothesis, indicating that the amount of change in those regions is as expected if mutation and random genetic drift were the sole evolutionary forces causing evolution. While morphological variation in shape variables of the Colombian samples could be explained by nonrandom factors, the Chilean sample for shape PC1 is nearest to the limit between stabilizing effect and neutrality, indicating that random factors probably played a prevalent role rather than phenotypic evolution in that region. However, there is a prevalence of non-randomness in the Chilean sample's shape PC2 variation. All other results higher than 0.1 suggest an acceleration of morphological evolution by nonrandom factors (e.g., gene flow, directional selection, phenotypic plasticity), which is predominant in all regions to lesser or greater degrees. The samples from Brazil and Pampas show high values in all cases, indicating the prevalence of non-random factors in the diversification of the populations that inhabited those regions, while as mentioned, the samples from Chile show high values for PC2 only, while both shape variables are high in Colombia's samples.

\section{Discussion}

The results obtained in the present study show that the Argentinean Pampas was closely related to other early Holocene American samples, particularly to those from Lagoa Santa and Camarones 14. In general, the late American samples differ from the early samples in the different regions studied, confirming the pattern of two sets of cranial morphologies which correspond to the early and late chronologies observed in previous studies (e.g., Neves and Pucciarelli 1991; Pucciarelli et al. 2010). The main changes between the early and late samples include neurocranial length, height and breadth, facial breadth, masticatory height, and to a lesser extent 

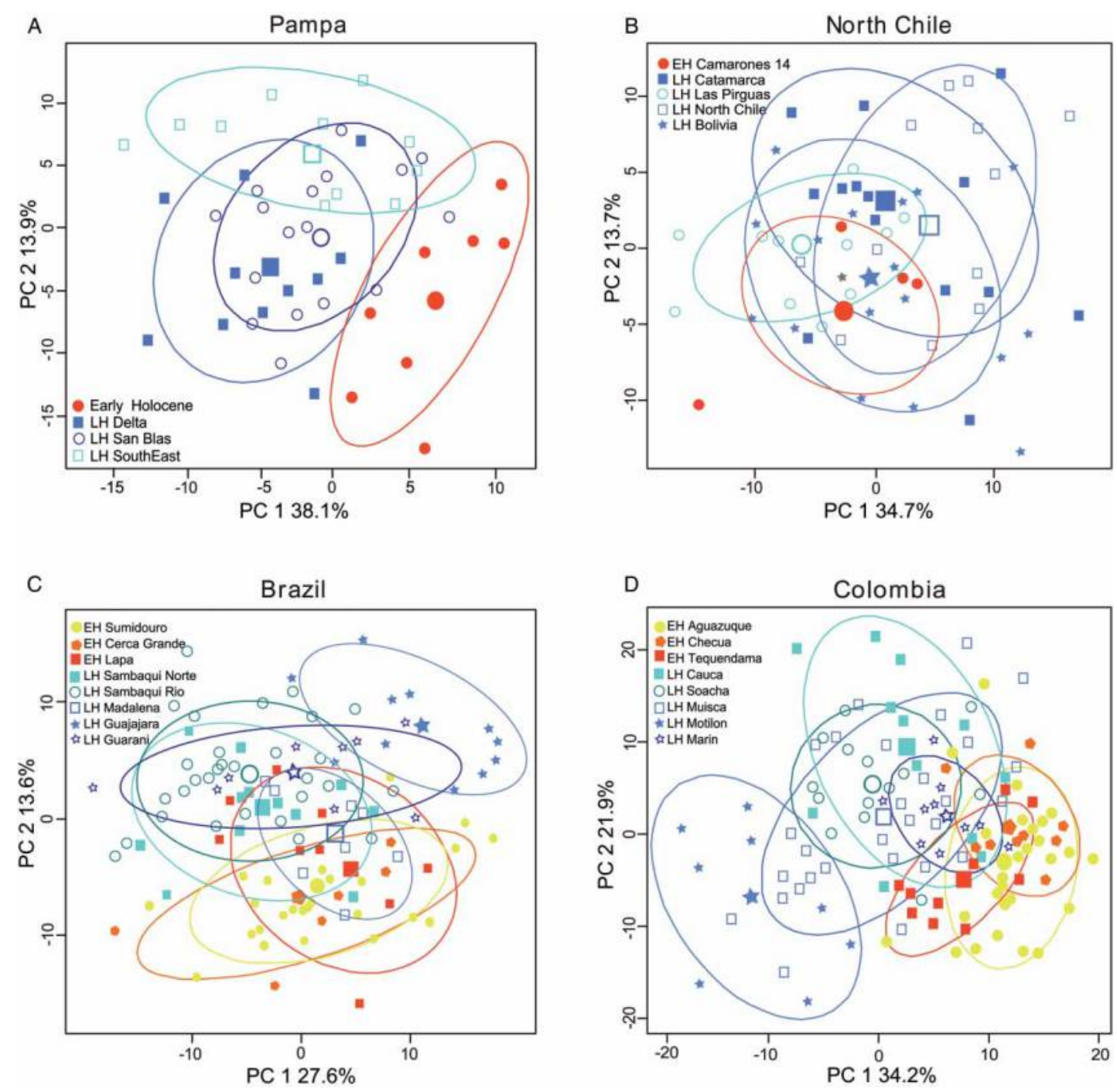

Figure 3 PCAs, with (A) Pampas samples, (B) Brazilian samples, (C) North Chile samples, and (D) Colombian samples. Large symbols indicate the sample means.

bizygomatic breadth, basion-bregma height, occipital length, and biasterionic breadth. These variations agree with the previously recognized pattern found in the Americas where early skulls (i.e., late Pleistocene and early Holocene samples) are characterized by a long and narrow cranial vault (i.e., dolichocephalic morphology), while more recent populations exhibit a shorter and wider cranial vault, that is, a brachycephalic morphology (Neves and Pucciarelli 1989; Neves et al. 2003; Powell and Neves 1999; Pucciarelli et al. 2010). The main hypothesis or model formulated to explain the differences between early and late

Table 6

Lynch's $\Delta$ evolutionary rate (bold numbers indicate $\Delta$ values higher than the null expectation)

\begin{tabular}{lccc}
\hline Sample & delta MG & delta PC1 & delta PC2 \\
\hline Pampa & 0.0457 & 0.0666 & 0.0213 \\
Colombia & 0.0035 & 0.3704 & 0.0686 \\
North Chile & 0.0050 & 0.0013 & 0.0256 \\
Brazil & 0.0261 & 0.0102 & 0.3403 \\
\hline
\end{tabular}

samples is the migratory hypothesis of two main biological components, which suggests that the biological variation among South American groups was the result of two successive migratory waves. According to this hypotheses, the first component (named "Paleoamericans" by Neves and Pucciarelli (1991)) derived from Pleistocene southeast Asian populations and expanded into America around $14,000{ }^{14} \mathrm{C}$ yr BP, while the second component (named "Amerindians" by Neves and Pucciarelli (1991)), from which most modern Native American groups are derived, corresponds to a migration coming from a northeast Asia population which may have occurred at the end of the early Holocene or in the middle Holocene (Neves and Hubbe 2005; Neves et al. 2003).

Nevertheless, in the regional analyses of the craniometric data from late and early samples, chronology seems not to be the single dimension to explain morphological differences among the samples. In the case of the Argentinean Pampas, Colombia, and Brazil, chronology is the main dimension behind the 
morphological differences, but this is not the case for the North Chilean sample. Thus, the peopling and diversification of South American populations is probably more complex than the two-wave migration hypothesis of Neves and Pucciarelli (1991) and Neves et al. (2003). Moreover, when mtDNA data of diachronic samples (from ca. 8000 to $400{ }^{14} \mathrm{C}$ yr BP) are compared, even the oldest individuals who display traits attributable to Paleoamerican crania (e.g., Argentinean Pampa samples) present the same DNA haplogroups as those of modern populations with Amerindian morphologies, suggesting no strong temporal DNA changes in the Americas (Chatters et al. 2014; Kemp et al. 2007; Perez et al. 2009; Rasmussen et al. 2014). Furthermore, in the sample from North Chile, both morphometric and mtDNA data suggest no differences between early and late populations (Moraga et al. 2005). This agrees with previous studies that concluded that the extant native populations inhabiting South Chile and Argentina are a group which had a common origin, and suggest a population break between the extreme south of South America and the more northern part of the continent, proposing the early colonization process included movements across the Andes (de Saint Pierre et al. 2012). Consequently, the interpretations of craniometric differences observed among the early and late samples need further study and discussions.

In this sense, the results regarding the rate of evolutionary change among the four geographical regions studied shows a heterogeneous picture. The results of Lynch's test presented here suggest that in some cases neutral processes are enough to explain morphological diversification of the human groups studied, while in other cases non-random processes had an important contribution. Whereas nonrandom factors could have been important in modeling shape evolution in Colombia and the North of Chile, and random factors could be sufficient to explain size changes in the Colombian and Chilean samples, all other results in Pampa and Brazil suggest an acceleration of morphological evolution by non-random factors, in some degree. This means that non-random factors could have played an important role in the diversification of human populations of South America. Although migration-and the concomitant gene flow-is a non-random factor to be taken into account (González-José et al. 2005; Neves et al. 2003), considering all previously discussed evidences (e.g., ancient DNA, modern mtDNA), one possible alternative hypothesis to explain the quantity and pattern of morphological variation in South America could be the action of local random (i.e., genetic drift) and/or non-random factors (e.g., selection and plasticity (Perez et al. 2009; Powell and Neves
1999)). This could be the case either if early and late groups have a last-common ancestor outside the continent (as in the dual-migration model supported by most of morphological studies) or if the early groups were the ancestors of late groups (as in the one-wave model supported by most of molecular studies). In relation to random factors, Hubbe et al. (2010) found high rates of morphological diversification, refuting the idea that the Amerindian morphology (i.e., late Holocene populations) is the result of neutral processes from Paleoindian morphology (i.e., early Holocene populations). This leads to rejection of the one-wave migration hypothesis and supports the two-wave hypothesis. On the other hand, de Azevedo et al. (2011) concluded that whatever the peopling scenario was (referring to one-wave or two-wave migration models), the morphological diversification rates match with neutral expectations, rejecting the two-wave model and supporting a recurrent geneflow model among circumpolar groups (de Azevedo et al. 2011; González-José et al. 2008). Otherwise, in relation to non-random factors-such as directional selection and phenotypic plasticity - these could have played an important role, too, considering the correspondence between craniofacial morphology and ecological variables, such as diet and climate, which are factors that have been previously observed (González-José et al. 2005; Perez and Monteiro 2009; Perez et al. 2009, 2011; Raff et al. 2011; Menéndez et al. 2014). From the results of the present study, both local random and non-random processes of morphological differentiation in America are a probable scenario, especially if a rapid South American peopling and the great ecological diversity of the continent are considered. This means that the significant morphological variation measured between early and late Holocene samples could be the result of ecological and microevolutionary local processes that acted on the diversification of regional groups (Fuselli et al. 2003).

Our results show major craniometric differences in cranial skeletons between early and late South American samples. However, this pattern is not homogeneous among all South American regions. Particularly, we found that the craniometric differences between the early and late Holocene American samples are greater in the Argentinean Pampas. On the basis of cranial morphometric differences alone, it is difficult to support the hypothesis that the morphological differences between early and late American samples are related to migratory process or selective/plasticity factors. This is because cranial morphology can change quickly, i.e., experience an unusually rapid evolutionary rate, due to all of these non-random factors (Carroll et al. 2007; Hendry and Kinnison 1999). Future studies should consider 
alternative models (Betti et al. 2014; Roseman and Auerbach 2015; Weaver et al. 2007) for asserting the relative roles that evolutionary processes have played in the shaping of South American morphological variation. Although both craniometric and archaeological evidence is very important to understand human peopling and diversification in the Americas, new research needs to consider additional lines of evidence (e.g., ancient DNA) in combination. Despite the difficulty of recovering ancient DNA (Kemp et al. 2007, Raff et al. 2011), future results derived from molecular and morphological data collected from the same populations (Hubbe et al. 2010) should be contrasted directly to elucidate if the genetic structure of American populations was already established with the founding groups. In the last decade, interesting results are emerging that delineate an even more complex scenario, overcoming the previous dichotomization of the one/two migratory waves (de Azevedo et al. 2011) or even the fact that not all molecular studies favor a one-migration model (Perego et al. 2009). Along the same path are the results obtained in the present research that, although large morphological differences were found between early and late Holocene groups, suggest the importance of non-random factors (i.e., selection and plasticity) to explain the morphological diversification of South American groups.

Above all, diversification of South American human groups was a complex process, and the concomitant morphological patterns seem to be the result of multiple factors and evolutionary processes in the different geographical regions.

\section{Acknowledgements}

The authors thank María Cristina Muñe, technician for Consejo Nacional de Investigaciones Científicas y Técnicas (CONICET), for her highly valuable collaboration in this study. The authors also thank the staff of the institutions from America and Europe mentioned in the text for granting access to the human skeletal collections under their care. We also thank Cecilia Morgan for help with the English version of the manuscript, as well as Mark Hubbe and an anonymous reviewer who suggested valuable comments that improved this paper.

\section{References}

Ameghino, Florentino. 1880. La antigüedad del Hombre en el Plata. Paris and Buenos Aires.

Ameghino, Florentino. 1884. Filogenia. Principios de clasificación transformista, basados sobre leyes naturales y proporciones matemáticas. Buenos Aires.

Ameghino, Florentino. 1889. "Contribución al conocimiento de los mamíferos fósiles de la República Argentina." Buenos Aires: Actas de la Academia Nacional de la República Argentina 6: 45-99.
Ameghino, Florentino. 1906. Les Formations sédimentaires du Crétacé supérieur et du Tertiaire de Patagonie. Buenos Aires: Anales del Museo Nacional 8.

Ameghino, Florentino. 1907. "Notas preliminares sobre el Tetraprothomo argentinus: un precursor del hombre del Mioceno superior de Monte Hermoso." Anales del Museo Nacional 9: 107-242. Buenos Aires.

Ameghino, Florentino. 1909. "Le Diprothomo platensis: un précurseur de íhomme du Pliocène inférieur de Buenos Aires." Buenos Aires: Anales del Museo Nacional de Buenos Aires 19(12): 107-209.

Ameghino, Florentino. 1910a. "La industria lítica del Homo Pampaeus, procedente de la región litoral de Mar del Plata a Necochea." Actas del XVII Congreso Cientifico Internacional Americano, 143-146.

Ameghino, Florentino. 1910b. "Descubrimiento de dos esqueletos humanos fósiles en el pampeano inferior del Moro." I Congreso Científico Internacional Americano, 10-25.

Ameghino, Florentino. 1912. "La callotte du Diprothomo d'après l'orientation frontoglabellaire." Anales del Museo Nacional 15: 1-9. Buenos Aires.

Béguelin, Marién. 2011. Variación Geográfica en la Morfología del Esqueleto Postcraneal de las Poblaciones Humanas de Pampa y Patagonia durante el Holoceno Tardio: Una Aproximación Morfométrica. BAR S2253. South America Archaeology Series N 12. England: Archaeopress.

Bernal, Valeria. 2008. Procesos de Diferenciación Biológica entre Poblaciones Humanas del Holoceno Tardio de Patagonia. Una aproximación desde la Variación Métrica Dental. PhD dissertation, Facultad de Ciencias Naturales y Museo, Universidad Nacional de La Plata, La Plata.

Betti, Lia, Noreen von Cramon-Taubadel, Andrea Manica, and Stephen J. Lycett. 2014. "The interaction of neutral evolutionary processes with climatically driven adaptive changes in the 3D shape of the human os coxae." Journal of Human Evolution 73: 64-74.

Bonomo, Mariano. 2002. "El Hombre Fósil de Miramar." Intersecciones en Antropología 3: 69-85.

Bonomo, Mariano, Clara Scabuzzo, and Catril Leon. 2013. "Cronología y dieta en la costa atlántica pampeana." Intersecciones en Antropología 14(1): 123-126.

Brace, Loring C, A. Russell Nelson, Noriko Seguchi, Hiroaki Oe, Leslie Sering, Pan Qifeng, Li Yongyi, and Dashtseveg Tumen D. 2001. "Old World sources of the first New World human inhabitants: a comparative craniofacial view." Proceedings of the National Academy of Sciences USA 98: 10017-10022.

Buikstra, Jane E., and Douglas H. Ubelaker. 1994. Standards for Data Collection from Human Skeletal Remains. Arkansas Archeological Survey Research Series 44. Fayetteville: Arkansas Archeological Survey.

Carroll, Scott P., Andrew P. Hendry, David N. Reznick, and Charles W. Fox. 2007. "Evolution on ecological time-scales." Functional Ecology 21(3): 387-393.

Cavalli-Sforza, Luigi Luca, Paolo Menozzi, and Alberto Piazza. 1994. The History and Geography of Human Genes. Princeton: Princeton University Press.

Chatters James, Douglas Kennett, Yemane Asmerom, Brian Kemp, Victor Polyak, Alberto Nava Blank, Patricia Beddows, Eduard Reinhardt, Joaquin Arroyo-Cabrales, Deborah Bolnick, Ripan Malhi, Brendan Culleton, Luna Erreguerena Pilar, Dominique Rissolo, Shanti Morell-Hart, and Thomas Stafford Jr. 2014. "Late Pleistocene human skeleton and mtDNA link Paleoamericans and modern Native Americans." Science 344: $750-754$.

Cornero, Silvia, Walter Neves, and Diego Rivero. 2014. "Nuevos aportes a la cronología de las ocupaciones tempranas en las Sierras de Córdoba. La Gruta de Candonga (Córdoba, Argentina)." Relaciones de la Sociedad Argentina de Antropología XXXIX(1): 285-292.

Daino, Leonardo. 1979. "Exégesis histórica de los hallazgos arqueológicos de la costa atlántica bonaerense." Prehistoria Bonaerense, 95-195. Olavarría: Municipalidad de Olavarría.

de Azevedo Soledad, Ariadna Nocera, Carolina Paschetta, Lucía Castillo, Marina González, and Rolando González-José. 2011. "Evaluating microevolutionary models for the early settlement of the New World: the importance of recurrent gene flow with Asia." American Journal of Physical Anthropology 146: 539-552.

de Saint Pierre, Michelle, Claudio M. Bravi, Josefina M. B. Motti, Noriyuki Fuku, Masashi Tanaka, Elena Llop, Sandro L. 
Bonatto, and Mauricio Moraga. 2012. "An alternative model for the early peopling of Southern South America revealed by analysis of three mitochondrial DNA haplogroups." PLoS One 7(9): e43486.

Fuselli, Silvia, Eduardo Tarazona-Santos, Isabelle Dupanloup, Alonso Soto, Donata Luiselli, and Davide Pettener. 2003. "Mitochondrial DNA diversity in South America and the genetic history of Andean highlanders." Molecular Biology and Evolution 20(10): 1682-1691.

Goebel, Ted, Michael R. Waters, and Dennis H. O’Rourke. 2008. "The Late Pleistocene dispersal of modern humans in the Americas." Science 319: 1497-1502.

González-José, Rolando, Silvia L. Dahinten, Maria A. Luis, Miquel Hernández, and Héctor M. Pucciarelli. 2001. "Craniometric variation and the settlement of the Americas: testing hypotheses by means of R matrix and matrix permutation tests." American Journal of Physical Anthropology 116: 154-166.

González-José, Rolando, Antonio González-Martín, Miquel Hernández, Héctor M. Pucciarelli, Marina Sardi, Alfonso Rosales, and Silvia Van der Molen. 2003. "Craniometric evidence for Palaeoamerican survival in Baja California." Nature 425: 62-65.

González-José, Rolando, Walter A. Neves, Marta Mirazón Lahr, Silvia González, Héctor M. Pucciarelli, Miquel Hernández, and Gonzalo Correal. 2005. "Late Pleistocene/Holocene cranial facial morphology in Mesoamerican Paleoindians: implications for the peopling of the New World." American Journal of Physical Anthropology 128: 772-780.

González-José, Rolando, Maria Cátira Bortolini, Fabricio Santos, and Sandro Bonatto. 2008. "The peopling of the America: craniofacial shape variation on a continental scale and its interpretation from an interdisciplinary view." American Journal of Physical Anthropology 137: 175-187.

Greenberg, Joseph H., Christy G. Turner II, and Stephen L. Zegura. 1986. "The settlement of the Americas: a comparison of the linguistic, dental and genetic evidence." Current Anthropology 27: 477-495.

Hendry, Andrew P., and Michael T. Kinnison. 1999. "The pace of modern life: measuring rates of contemporary microevolution." Evolution 53: 1637-1653.

Howells, William W. 1973. "Cranial variation in man: a study by multivariate analysis of patterns of difference among recent human populations." Papers of the Peabody Museum of Archaeology and Ethnology 67: 1-259.

Hrdlička, Aleš. 1912. Early Man in South America. Bulletin 52. Washington: Smithsonian Institution, Bureau of American Ethnology.

Hubbe, Mark, Walter A. Neves, and Katerina Harvati. 2010. "Testing evolutionary and dispersion scenarios for the settlement of the New World." PLoS One 5: e11105. doi:10.1371/ journal.pone.0011105.

Jackson, Donald, César Méndez, and Eugenio Aspillaga. 2012. "Human remains directly dated to the Pleistocene-Holocene transitions support a marine diet for early settlers of the Pacific coast of Chile." Journal of Island \& Coastal Archaeology 7: 363-377.

Jantz, Richard L., and Douglas W. Owsley. 2001. "Variation among early North American crania." American Journal of Physical Anthropology 114: 146-155.

Jungers, William L., Anthony B. Falsetti, and Christine E. Wall. 1995. "Shape, relative size, and size-adjustments in morphometrics." Yearbook of Physical Anthropology 38: 137-161.

Kemp, Brian M., Ripan S. Malhi, John McDonough, Deborah A. Bolnick, Jason A. Eshleman, Olga Rickards, Cristina Martinez-Labarga, John R. Johnson, Joseph G. Lorenz, E. James Dixon, Terence E. Fifield, Timothy H. Heaton, Rosita Worl, and David G. Smith. 2007. "Genetic analysis of early Holocene skeletal remains from Alaska and its implications for the settlement of the Americas." American Journal of Physical Anthropology 132: 605-621.

Knussman, Rainer. 1988. Anthropologie: Handbuch der Vergleichenden Biologie des Menschen. Stuttgart: Gustav Fischer Verlag.

Lahr, Marta Mirazón. 1996. The Evolution of Modern Human Diversity: A Study of Cranial Variation. Cambridge: Cambridge University Press.

Lehmann-Nitsche, Robert. 1907. "Nouvelles rechrerches sur la formation pampeénne et ĺhomme fossile de la République Argentine." Revista del Museo de La Plata 14(1): 143-479.
Lynch, Michael. 1990. "The rate of morphological evolution in mammals from the standpoint of the neutral expectation." American Naturalist 136: 727-741.

Lund, Peter W. 1842. "Carta escripta de Lagoaa Santa ao senhor Primeiro Secretário do Instituto." Revista do Instituto Histórico e Geográfico Brasileiro 4: 30-87.

Martin, Rudolf, and Karl Saller. 1959. Lehrbuch der Anthropologie. Stuttgart: Gustav Fischer Verlag.

Mena, Francisco, Omar Reyes, Thomas W. Stafford, and John Southon. 2003. "Early human remains from Baño Nuevo-1 cave, central Patagonian Andes, Chile." Quaternary International 109: 113-121.

Menéndez, Lumila, Valeria Bernal, Paula Novellino, and S. Ivan Perez. 2014. "Effect of bite force and diet composition on craniofacial diversification variation on southern south America populations." American Journal of Physical Anthropology 155: $114-127$.

Moraga, Mauricio, Calogero M. Santoro, Vivien G. Standen, Pilar Carvallo, and Francisco Rothhammer. 2005. "Microevolution in prehistoric andean populations: chronologic mtDNA variation in the desert valleys of Northern Chile." American Journal Physical Anthropology 127(2): 170-181.

Moss, Melvin L., and Richard W. Young. 1960. "A functional approach to craniology." American Journal of Physical Anthropology 18: 281-292.

Neves, Walter A., and Héctor M. Pucciarelli. 1989. "Extra-continental biological relationships of early South American human remains: a multivariate analysis." Ciencia Cultura 41: 566-575.

Neves, Walter A., and Héctor M. Pucciarelli. 1991. "Morphological affinities of the first Americans: an exploratory analysis based on early South American human remains." Journal of Human Evolution 21: 261-273.

Neves, Walter A., and Mark Hubbe. 2005. "Cranial morphology of early Americans from Lagoa Santa. Brazil: implications for the settlement of the New World." Proceedings of the National Academy of Sciences 102: 18309-18318.

Neves, Walter A., Joseph E. Powell, and Erik G. Ozolins. 1999. "Extra-continental morphological affinities of Lapa Vermelha IV, Hominid 1: a multivariate analysis with progressive numbers of variables." Homo 50(3): 263-282.

Neves, Walter A., André Prous, Rolando González-José, Renato Kipnis, and Jeffrey Powell. 2003. "Early Holocene human skeletal remains from Santana do Riacho, Brazil: implications for the settlement of the New World." Journal of Human Evolution 45: 759-782.

Neves, Walter A., Mark Hubbe, and Gonzalo Correal. 2007. "Human skeletal remains from Sabana de Bogotá, Colombia: a case of Paleoamerican morphology late survival in South America?" American Journal of Physical Anthropology 133: 1080-1098.

Perego, Ugo, Alessandro Achilli, Norman Angerhofer, Matteo Accetturo, Maria Pala, Anna Olivieri, Kashani Baharak Hooshiar, Kathleen Ritchie, Rosaria Scozzari, Qing-Peng Kong, Natalie Myres, Antonio Salas, Ornella Semino, HansJürgen Bandelt, Scott Woodward, and Antonio Torroni. 2009. "Distinctive Paleo-indian migration routes from Beringia marked by two rare mtDNA haplogroups." Current Biology 19: 1-8.

Perez, S. Ivan, and Leandro R. Monteiro. 2009. "Nonrandom factors in modern human morphological diversification: a study of craniofacial variation in southern South American populations." Evolution 63(4): 978-993.

Perez, S. Ivan, Valeria Bernal, Paula N. Gonzalez, Marina Sardi, and Gustavo G. Politis. 2009. "Discrepancy between cranial and DNA data of early Americans: implications for American peopling." PLoS One 4(5): e5746; doi:101371/ journal.pone.0005746.

Perez, S. Ivan, Verónica Lema, J. A. F. Diniz-Filho, Valeria Bernal, Paula N. Gonzalez, Diego Gobbo, and Héctor M. Pucciarelli. 2011. "The role of diet and temperature in shaping cranial diversification of South American human populations: an approach based on spatial regression and divergence rate tests." Journal of Biogeography 38: 148-163.

Podgorny, Irina. 2015. "Human origins in the New World? Florentino Ameghino and the emergence of prehistoric archaeology in the Americas." PaleoAmerica 1: 68-80.

Politis, Gustavo G., and Mariano Bonomo. 2011. "Nuevos datos sobre el 'Hombre Fósil' de Ameghino." Publicación Especial APA 12: 101-135. 
Politis, Gustavo G., Gustavo Barrientos, and Thomas W. StaffordJr. 2011. Revisiting Ameghino: new ${ }^{14} \mathrm{C}$ dates from ancient human skeletons from the Argentine Pampas. In Peuplements et Préhistorie en Amériques, edited by Denis Vialou, 43-53. Paris: Editorial du CTHS.

Politis, Gustavo G., Pablo G. Messineo, Mariela E. González, María C. Álvarez, and Christian Favier Dubois. 2012. "Primeros resultados de las investigaciones en el sitio Laguna de Las Pampas (partido De Lincoln, provincia de Buenos Aires)." Relaciones de la Sociedad Argentina de Antropología 37(2): 463-472.

Politis, Gustavo G., María A. Gutiérrez, and Clara Scabuzzo, eds. 2014. Estado Actual de las Investigaciones en el Sitio Arroyo Seco 2 (Partido de Tres Arroyos, Provincia de Buenos Aires, Argentina). Olavarría: Serie Monográfica No. 5. INCUAPACONICET, UNICEN.

Powell, Jeffrey F., and Walter A. Neves. 1999. "Craniofacial morphology of the first Americans: pattern and process in the peopling of the New World." Yearbook of Physical Anthropology 42: $153-188$

Pucciarelli, Héctor M. 2008. Evolución y Diversificación Biológica Humana desde la Perspectiva Craneofuncional. México D.F.: Universidad Autónoma de México.

Pucciarelli, Héctor M., Vicente Dressino, and Mario H. Niveiro. 1990. "Changes in skull components of the squirrel monkey evoked by growth and nutrition: an experimental study." American Journal of Physical Anthropology 81: 535-543.

Pucciarelli, Héctor M., Marina L. Sardi, José C. Jimenez López, and Carlos Serrano Sanchez. 2003. "Early peopling and evolutionary diversification in America." Quaternary International 109: 123-132.

Pucciarelli, Héctor M., Walter A. Neves, Rolando González-José, Marina L. Sardi, Fernando Ramírez Rozzi, Adelaida Struck, and Mary Y. Bonilla. 2006. "East-west cranial differentiation in pre-Columbian human populations of South America." Homo 57: 133-150.

Pucciarelli, Héctor M., S. Ivan Perez, and Gustavo G. Politis. 2010. "Early Holocene human remains from the Argentinean Pampas: additional evidence for distinctive cranial morphology of early South Americans." American Journal of Physical Anthropology 143 (2): 298-305.

Raff, Jeniffer A., Deborah A. Bolnick, Justin Tackney, and Dennis H. ÓRourke. 2011. "Ancient DNA perspectives on American colonization and population history." American Journal of Physical Anthropology 146: 503-514.

Rasmussen, Morten, Sarah L. Anzick, Michael R. Waters, Pontus Skoglund, Michael DeGiorgio, Thomas W. Stafford Jr, Simon Rasmussen, Ida Moltke, Anders Albrechtsen, Shane M. Doyle, G. David Poznik, Valborg Gudmundsdottir, Rachita Yadav, Anna-Sapfo Malaspinas, Samuel StocktonWhiteV, Morten E. Allentoft, Omar E. Cornejo, Kristiina Tambets,
Anders Eriksson, Peter D. Heintzman, Monika Karmin, Thorfinn Sand Korneliussen, David J. Meltzer, Tracey L. Pierre, Jesper Stenderup, Lauri Saag, Vera M. Warmuth, Margarida C. Lopes, Ripan S. Malhi, Søren Brunak, Thomas Sicheritz-Ponten, Ian Barnes, Matthew Collins, Ludovic Orlando, Francois Balloux, Andrea Manica, Ramneek Gupta, Mait Metspalu, Carlos D. Bustamante, Mattias Jakobsson, Rasmus Nielsen, and Eske Willerslev. 2014. "The genome of a late Pleistocene human from a Clovis burial site in western Montana." Nature 506: 225-229.

Roseman, Charles C., and Benjamin M. Auerbach. 2015. "Ecogeography, genetics, and the evolution of human body form." Journal of Human Evolution 78: 80-90.

Roth, Santiago. 1888. "Beobachtungen über entstehung und Alter Pampasformation in Argentinien." Zeitschrift der Deutschen Geologischen Gesellschaft 40: 375-464.

Rubin, Donald B. 1987. Multiple Imputation for Nonresponse in Surveys. New York: John Wiley \& Sons.

Sardi, Marina L., Fernando Ramírez Rozzi, Rolando GonzálezJosé, and Héctor M. Pucciarelli. 2005. "South Amerindian craniofacial morphology: diversity and implications for Amerindian evolution." American Journal of Physical Anthropology 128: 747-756.

Stringer, Christopher B. 1992. Replacement, continuity and the origin of Homo sapiens. In Continuity or Replacement: Controversies in Homo sapiens Evolution, edited by Guenter Bräuer and Fred H. Smith, 9-24. Balkema: Rotterdam.

Steele, Genry D., and Claude A. Bramblett. 1988. The Anatomy and Biology of the Human Skeleton. College Station: Texas A\&M University Press.

Steele, D. Gentry, and Joseph Powell. 1992. "Peopling of the Americas: Paleobiological evidence." Human Biology 64: 303-336.

Steele, D. Gentry, and Joseph Powell. 1993. "Paleobiology of the first Americans." Evolutionary Anthropology 2: 138-146.

Stuiver, Minze, and Ron W. Reimer. 2011. CALIB 6.1.1. http://calib. qub.ac.uk/calib/.

Turner II, Christy G. 1983. "Dental evidence for the peopling of the Americas." In Early Man in the New World, edited by Richard Shutler, 147-157. Beverly Hills: Sager Publications.

van der Klaauw, Christiaan J. 1948-1952. "Size and position of the functional components of the skull." Archives Néerlandaises de Zoologie 9: 1-559.

Virchow, Rudolf. 1883. "Ein mit Glyptodon-Resten gefundenes meneschliches skelet aus der Pampa de la Plata." Verhandlungen Berliner Gesellsdchaft Anthropologie Ethnologie Urgeschichte 15: 465-467.

Weaver, Timothy D., Charles C. Roseman, and Chris B. Stringer. 2007. "Were Neandertal and modern human cranial differences produced by natural selection or genetic drift?" Journal of Human Evolution 53: 135-145.

\section{Author's Biographies}

Lumila Paula Menéndez, bioanthropologist (PhD 2014, Facultad de Ciencias Naturales y Museo, UNLP), is Teaching Assistant at Universidad Nacional de La Plata (UNLP) and a Postdoctoral fellow with the National Council for Scientific and Technical Research (CONICET), Archaeology Department, Museo de La Plata, Argentina.

Sergio Ivan Perez, bioanthropologist (PhD 2006, Facultad de Ciencias Naturales y Museo, UNLP), is Senior Researcher with the National Council for Scientific and Technical Research (CONICET), Anthropology Department, Museo de La Plata, Argentina.

Héctor M. Pucciarelli, bioanthropologist (PhD 1971, Facultad de Ciencias Naturales y Museo, UNLP), is Emeritus Professor at Universidad Nacional de La Plata (UNLP), Senior Researcher with the National Council for Scientific and Technical Research (CONICET), and Chief of the Anthropology Department at Museo de La Plata, Argentina.

Mariano Bonomo, archaeologist (PhD 2004, Facultad de Ciencias Naturales y Museo, UNLP), is Professor at Universidad Nacional de La Plata (UNLP) and Senior Researcher with the National Council for Scientific and Technical Research (CONICET), Archaeology Department, Museo de La Plata, Argentina. 
Pablo Gerónimo Messineo, archaeologist (PhD 2008, Facultad de Ciencias Naturales y Museo, UNLP), is Assistant Professor in the Department of Archaeology, Facultad de Ciencias Sociales, UNICEN, and Assistant Researcher with the National Council of Scientific and Technological Investigations (CONICET), Argentina.

Mariela Edith Gonzalez, archaeologist (PhD 2012, Facultad de Ciencias Sociales, UNICEN), is Teaching Assistant in the Department of Archaeology, Facultad de Ciencias Sociales, UNICEN, and Assistant Researcher for the National Council of Scientific and Technological Investigations (CONICET), Argentina.

Gustavo Politis, archaeologist (PhD 1984, Facultad de Ciencias Naturales y Museo, UNLP), is Professor at the Universidad Nacional del Centro de la provincia de Buenos Aires and at the Universidad Nacional de La Plata, and Senior Researcher with CONICET (National Council of Scientific and Technological Investigations), Department of Archaeology, UNICEN, Argentina. 